DOI: 10.17707/AgricultForest.63.3.04

\title{
Seyed Hamid Reza SADEGHI \\ SOIL EROSION IN IRAN: STATE OF THE ART, TENDENCY AND SOLUTIONS
}

\begin{abstract}
SUMMARY
Soil erosion mirrors the complex interactions among living and non-living elements in a watershed system. Any type of imbalance in watershed components leads to unexpected and unwished outcomes causing loss of infrastructures and investments. Different figures from 0.8 to even 7 billion tones have been given on soil erosion rate in Iran, progressively increased during last decades. Untimely erosive rain, high potential sensitivity of resources, improper infrastructures development, land use changes, and unlawful/over exploitation of resources are the main reasons behind ever-increasing soil erosion. However, many attempts made by authorized organizations and agencies could simply brake down the high rate of the erosion. In the present article, it was aimed to report some managerial approaches for minimizing the soil erosion-related problems towards developing integrated watershed management approach in Iran.

Keywords: CoManagement Practice, Ecosystem Services, Land Use Planning, Sediment Yield
\end{abstract}

\section{INTRODUCTION}

Soil erosion is a very complicated process mirrors the resultant of complicated interactions among many existing factors in a watershed system. Elucidating soil erosion phenomenon and magnitude can therefore represents balance level in the watershed systems and provides a useful index of land degradation, soil erosion severity and trends. Accurate estimates of sediment yield and its temporal variation are needed for various purposes, including the design of impoundments and erosion control structures, river morphological computations, and evaluation studies of the effects of various land use management practices (Kothyari et al., 1997; Lana-Renault et al., 2007; Emadodin et al., 2012; Eskandarie, 2012; Zakerinejad and Maerker, 2015).

There are many controlling factors on the severity and extension the soil erosion many of which either originates or accelerates by the human (Hudson and Alcantara-Ayala, 2006; Sadeghi et al., 2008; Sadeghi, 2009; Emadodin et al., 2012). In the present paper, an attempt is firstly made to minutely picture and elaborate the existing problems in the country. Some scientific reports on drastic

\footnotetext{
${ }^{1}$ Sadeghi Sayed Hamid Reza (corresponding author: sadeghi@modares.ac.ir), Department of Watershed Management Engineering, Faculty of Natural Resources, Tarbiat Modares University, Noor 4641776489, Mazandaran, President of the Watershed Management Society of Iran, IRAN. Presented at the 7th International Symposium of Ecologists (ISEM7), Sutomore, Montenegro. Notes: The authors declare that they have no conflicts of interest. Authorship Form signed online.
} 
changes in sediment fluxes due to natural and human induced factors will also be presented. The appropriate solutions will also be presented to combat or minimize the problems towards developing effective sediment management strategies.

\section{Soil Erosion in Iran}

\section{RESULTS AND DISCUSSION}

Collecting an appropriate data set on soil erosion is essential to draw the sustainable managerial strategies for a watershed management, since soil erosion stands at the top priority (Singh, 2003; Ghazanfari et al. 2003; Emadodin et al., 2012; Eskandarie, 2012; Sadeghi and Cerda, 2015; Zakerinejad and Maerker, 2015) among different types of land degradation. It is used for the integrated watershed management which aims at coordinating various sectors in the national level in order to protect the safety of the people and arriving at economically productive, socially equitable, and environmentally sustainable watershed needs.

Iran, with an area of ca $1800000 \mathrm{~km} 2$, encounters soil erosion problems. Some 100 Mha of Iranian territory are exposed to erosion or other types of chemical and physical degradation (Kheyrodin, 2016). Water erosion is one of the most important types of land degradation in most parts of Iran destroying fertile soils and agricultural land. Nearly 35 Mha of the Iran is influenced by different types of water erosion (Zakerinejad and Maerker, 2015). Since 1960's serious soil erosion problem was initially considered by watershed managers and experts. Since then many attempts were made to picture a proper view of soil erosion in the country led to many progressing figures and mainly horribly unreliable from 0.8 to even 8 billion tons per annum i.e., some inundation rates of 7 to 70 t.ha-1.Y-1. On average, soil erosion in Iran is three times more than other Asian countries and 20 times over the global average, and it is one of the highest in the world.

(www.tehrantimes.com/news; www.financialtribune.com/articles/environment).

According to official statistics of Ministry of Energy of Iran (www.daminfo.wrm.ir/tabularview-fa.html), there are 281 functioning dams in Iran, though some 700 other small and large dams are also under construction or study. As per bathymetric surveys of 27 large dams with watershed area of some 27 Mha and total volume of $24.2 \mathrm{bm} 3$, almost $132.7 \mathrm{Mm} 3$ ( 172.5 Mt) sediment enters the dams reservoirs annually. It verifies a denudation rate of $6.28 \mathrm{t}$ ha-1y-1 and annual volume reduction of $0.54 \%$. These figures clearly represent very severe soil erosion rates in Iran. It not only has been causing rapid reduction of reservoirs life time but also causes some $400 \mathrm{Mm} 3$ sedimentation in downstreams with an important loss of irrigation lands and power generation capacity (Sharifi and Ghafouri, 2007).

Soil erosion in Iran is so high that it is costing the country USD 56 to 112 billion every year depending on different rates of soil erosion (www.tehrantimes.com/news). So that it costs more than oil revenue in Iran (www.financialtribune.com/articles/environment). 


\section{Controlling Factors}

There are many affecting factors controlling the severity and extension of soil erosion in Iran. Iran, as one of the progressing countries, currently faces many soil erosion issues. Iran natural environment is under increasing strain due to the combined effects of over-exploitation by communities and industry and changes in climate patterns (MENARID, 2017). High potential sensitivity of resources, improper and unnecessary infrastructures development, land use changes and unlawful exploitation of resources all are supposed as main reasons behind soil erosion in Iran (Sadeghi, 2009). However, inattention to soil value, limited numbers of hydrometry stations, short term data collection period, unreliable and opponent data and information, misunderstanding of the sediment yield processes and people's and experts' apathies mask the severity and intensity of the problem. As it is seen most of the affecting factors are similar to those oftreported throughout the globe instead some of them may be very specific. Nowadays, increase in watershed sediment yields resulting from human activities is a major concern in Iran like many other progressing countries (Sadeghi et al., 2008; Sadeghi and Saeidi, 2009; Sadeghi et al., 2009; UNESCO, 2009; Emadodin et al., 2012; Eskandarie, 2012; Sadeghi and Cerda, 2015; Zakerinejad and Maerker, 2015). In the following some important affecting factors on soil erosion in Iran have been listed.

-Very diversified natural conditions

- High potential sensitivity of resources

- Improper and unsuitable developmental activities

-Land use changes and unlawful exploitation of resources

-Not existing proper marketing of soil and ecosystem services

-Technical factors

\section{Mitigating Soil Erosion}

Despite many serious issues related soil erosion in Iran, still no practical, comprehensive country-wide strategy has been tried to manage soil erosion. Though many watershed management activities have been sparsely implemented throughout the country whose effectiveness have not been accurately and scientifically assessed yet. However, the following approaches can be suggested to control soil erosion in Iran (Sadeghi et al., 2008; Sadeghi and Saeidi, 2009; Sadeghi et al., 2009; UNESCO, 2009; Emadodin et al., 2012; Eskandarie, 2012; Sadeghi and Cerda, 2015; Zakerinejad and Maerker, 2015).

Proper understanding and conceptualizing the system leading to adaptive management

Limiting unnecessary infrastructures development and off-region activities

Controlling land use changes and stopping illogical exploitation of resources

Monitoring hydrological behavior of watersheds

Designating specific soil erosion measures for different agroecologic regions 


\section{CONCLUSION}

An attempt was made to picture soil erosion rates in Iran. Accordingly, affecting factors and related solutions were also concluded. The progressing inundations rates of soil erosion and hardening the related issues were also proved in Iran. A national level strategy and comanagement approaches with intimate belief of decision makers, experts and managers for drawing appropriate plans are essentially needed to control soil erosion related issues in Iran.

\section{REFERENCES}

Emadodin, I., Narita, D. \& Bork, H.R. (2012) Soil Degradation and Agricultural Sustainability: An Overview from Iran. Environ. Dev. Sustain. Doi: 10.1007/s10668-012-9351-y.

Eskandarie, B. (2012) Country Report on History and Status of Soil Survey in Iran. In: GSP regional workshop, Jordan, Amman 1-5 April 2012, 25p.

Ghazanfari, H., Namiranian, M., Sobhani, H. \& Mohadjeri, R. (2003) Traditional forest management and its application to encourage public participation for sustainable management of forest resources in northern Zagros (KurdistanIran), In: Abstract Proceedings of The international IUFRO Workshop: The Forest Science/Policy Interface in Europe, Africa and the Middle East, June 23-27, 2003, Copenhagen, Denmark, www.flec.kvl.dk/scipol/Abstracts.pdf

Hudson P.F. \& Alcantara-Ayala, I. (2006) Ancient and modern perspectives on land degradation, Catena, 65, 102-106.

Kheyrodin, H. (2016). Modeling Soil Erosion in Iran. Innovat Intl. J. Med. Pharmac. Sci., 1(1): 1-12.

Kothyari, U.C., Tiwari, A.K. \& Singh, R. (1997) Estimation of temporal variation of sediment yield from small catchments through the kinematic method, J. Hydrol., 203, 39-57.

Lana-Renault, N., Regüés, D., Martí-Bono, C., Beguería, S., Latron, J., Nadal, E., Serrano, P. \& García-Ruiz, J.M. (2007) Temporal variability in the relationships between precipitation, discharge and suspended sediment concentration in a small Mediterranean mountain catchment, Nordic Hydrol., 38 (2), 139-150.

MENARID (2017) Reducing Ecosystem Degradation in Iran. 2p.

Sadeghi, S.H.R. (2009). An overview on sediment problems and management in Iran. Sediment Problems and Sediment Management in Asian River Basins, In: Proceedings of the ICCE Workshop, Hyderabad, India, Sep. 2009. IAHS Publ. 349, 2011:14-20.

Sadeghi, S.H.R. \& Cerda, A. (2015). Soil erosion in Iran: Issues and solutions. Geoph. Res. Abs., Vol. 17, EGU2015-15840-1, 2p.

Sadeghi, S.H.R., Mizuyama, T., Miyata, S., Gomi, T., Kosugi, K., Fukushima, T., Mizugaki, S. \& Onda, Y. (2008) Determinant factors of sediment graphs and rating loops in a reforested watershed, J. Hydrol., 356, 271-282.

Sadeghi, S.H.R. \& Saeidi, P. (2009) Accuracy of decentation technique for estimation of different suspended sediment concentrations, In: Abstracts Proceedings of International Conference on Land Conservation- 
LANDCON0905, Serbia, Tara Mountain Park, May 26 to 30, 2009: 118 (Full paper published in CD, 4p).

Sadeghi, S.H.R., Saeidi, P., Noor, H. \& Raeisi, M.B. (2009) Understanding sediment yield processes in a Hyrcanian Forest Watershed, In: Abstracts Proceedings of International Conference on Land Conservation-LANDCON0905, Serbia, Tara Mountain Park, May 26 to 30, 2009: 119.

Sharifi I, F. \& Ghafouri, M. (2007) Assessment of causes and effects of disastrous erosion and sediment flows and mitigation measures in Caspian Sea Watersheds-Iran, In: Proceedings of Expert Meeting on Erosion and Sedimentation in Arid and Semi-Arid Regions, Chaloos, Iran, April 15-19, 2007:1-17.

Singh, R.V. (2003) Watershed Planning and Management, Yash Publishing House, India, 625p.

UNESCO (2009) Integrated Water Resources Management Guidelines at River Basin Level, Part 1, 24p.

Zakerinejad, R. \& Maerker, M. (2015) An Integrated Assessment of Soil Erosion Dynamics with Special Emphasis on Gully Erosion in the Mazayjan Basin, Southwestern Iran. Nat. Hazards 79:S25-S50.

www.daminfo.wrm.ir/tabularview-fa.html

www.financialtribune.com/articles/environment/33787

www.tehrantimes.com/news 